\title{
TASK-BASED LEARNING AT TEACHING GRAMMAR FOR PRE-SERVICE ENGLISH TEACHERS
}

The article deals with the problem of rethinking of the design and delivery of pre-service foreign language teacher education programmes.

The article shows the difference between PPT approach and task-based approach to learning. First of all, the author gives the definition of the notion "task" and its characteristics, "task-based learning" and the benefits learners can get from task-based learning (TBL). Task is a kind of an activity plan, which has the resource to promote foreign language use in the classroom. The main peculiar features of a task are 1) initial attention to meaning; 2) emphasis on language forms; 3) focus on how language is used in the real world.

Task-based learning is an approach where learners carry out tasks such as solving a problem or planning an activity and the language learnt comes out of the linguistic demands of the activity. The benefits of TBL are 1) students are placed in a situation like in the real world; 2) students use their skills at their current level, to help develop language through its use; 3) students achieve their goals where language becomes a tool, making the use of language a necessity.

The role of a teacher as a facilitator at the TBL lesson is described in the article. They must help learners to recognize differences and similarities; help them to improve their perceptions of the foreign language.

There are criteria for identifying tasks for TBL presented in the form of six questions. Based on these criteria there are several types of tasks: listing and brainstorming, matching, ordering and sorting, comparison, problem-solving, sharing personal experiences and storytelling.

The examples of grammar tasks for TBL are presented in the article. These examples relate to practical and theoretical English grammar courses. The author uses three phases of task-based activities, such as pretask activities, task - planning - report cycle, and post-task activities. Each phase to present to present TBL activities has its own aim and objectives.

Key words: task, task-based learning, grammar, criteria for identifying tasks, types of tasks.

Problem statement. The aspects of the methodology of foreign language teaching have constantly been researched and improved. The required improvement can only be achieved if we reconsider the structure and delivery of foreign language teacher education programmes. The traditional approach, when English is taught only with the emphasis on knowledge of grammar rules and vocabulary and little need to view the language as a means of communication, is not relevant and sufficient. The Council of Europe has set internationally accepted standards for proficiency in foreign languages by publication the Common European Framework of Reference for Languages. Ukraine has started to set the desirable levels of English for school leavers and university graduates. But these standards will remain insubstantial until the standards of English teaching at schools and universities are raised.

It is now widely known that lecturing is not an efficient way of delivering the content on a practical or theoretical course. The use of case studies, simulations, group projects, problem solving, and task-based learning are aimed at promoting active interaction and student involvement in their own learning processes.

Relevant studies analysis. Many authors have devoted their researches and findings to the problem of the quality of pre-service foreign language teacher education, approaches and ways of delivering material on foreign language courses, etc.

In his article on reconceptualization of language teacher education for the $21^{\text {st }}$ century Rod Bolitho distinguishes the obstacles to progress in language teacher education, examines what demands will be placed on the next generation of language teachers, skills and knowledge they will need, what courses we need for pre-service foreign language teacher education [1]. The researcher suggests the key characteristics of foreign language teacher education programmes, namely flexibility, interdisciplinarity and intercultural studies, generativeness; they should be holistic in concept, taught by a team, school-oriented in concept and delivery; they should have developmental dimension, objectives and global dimension [1].

The aim of our article is to analyze the efficiency of task-based approach at teaching grammar for pre-service English teachers.

Statement of basic materials. Most teachers are familiar with PPT paradigm to conduct classes. At the beginning of the lesson a teacher presents a notion of language in a clear manner. This can be done in several ways: using a text, giving a situation, a dialogue etc. 
Students then perform a controlled practice stage, where they may have to repeat target language through drilling, fill gaps or match halves of sentences. This practice is aimed at using the language correctly by the student and it helps them to get more familiar with it.

The final stage is the production stage or free practice stage. Students have to do a communication task such as acting out a dialogue or a role play and they are expected to produce the target language and use other language that has already been learnt and is suitable for doing it.

Task-based learning is an alternative way to study foreign language. In a task-based lesson the main focus is a task; the lesson is based around the completion of this task.

There are many definitions of the term "task" in task-based language teaching. These definitions involve a focus on language use, and the adjustment of meaning in order to achieve a real purpose.

Rod Ellis's definition is quite useful, because it describes a task as: 1) an activity managed by the teacher in the classroom; 2) an instrument used by researchers to understand classroom interaction and processes of language learning [2].

Rod Ellis considers a task as a work plan that requires learners to process language pragmatically in order to achieve an outcome that can be evaluated in terms of whether the correct or appropriate propositional content has been conveyed. To this end, it requires them to give primary attention to meaning and to make use of their own linguistic resources, although the design of the task may predispose them to choose particular forms. A task is intended to result in language use that bears a resemblance, direct or indirect, to the way language is used in the real world. Like other language activities, a task can engage productive or receptive, and oral or written skills, and also various cognitive processes [2, p. 16].

This definition specifies three major characteristics of tasks, namely 1) the primary attention to meaning is emphasized in terms of propositional content and pragmatics. For example, a task might consist of working with a series of pictures and defining the initial meaning of the pictures and what they represent. Learners might also relate the images for their own cultural context or background; 2) there is an emphasis on language forms. In using linguistic resources and choosing particular forms, e. g., the students engage in decisions such as the tense to be used in telling a story, or the particular adjective to represent different emotions; 3 ) there is a focus on how language is used in the real world. In this context he teacher has to set up a task: the activity should perfectly correspond to how the students use language already, or how they might aspire to using the target language. For example, if using a picture story task in a context where students are preparing for an examination in which grammatical accuracy is an important criterion, the task outcome might focus on writing an account. In another context, students might focus on telling the story as an anecdote in a social situation, or re-constructing the actions depicted in the story.

The researcher's definition ends with a reference to various cognitive processes. This is a link to the mechanisms of language learning that have been identified as important in second language acquisition research.

To sum up, a task is a kind of a work plan, which has the potential to promote foreign language use in the classroom.

While implementing, task is effective when it captures the imagination of the students and engages them in being both creative and flexible: in using the foreign language in unique, entertaining way, while at the same time conforming to the requirements of the task outcome, and to the accuracy and appropriateness of foreign language forms.

That is why task-based learning (TBL) is considered to be a different way to teach foreign languages. It can help students by placing them in a situation like in the real world, a situation where oral communication is essential for doing a specific task. Task-based learning has the advantage of getting the students to use their skills at their current level, to help develop language through its use. It has the advantage of getting the focus of the student toward achieving a goal where language becomes a tool, making the use of language a necessity.

One of the purposes of choosing TBL is to increase learners' activity. TBL is focused on learner and not teacher activity and the teacher's liability is to produce and supply different tasks which will give the learner an opportunity to experiment at once, individually and originally with the foreign language. Each task will provide the learner with new personal experience with the foreign language and at this point the teacher has a very important part to play. Michael Lewis supposes that teachers must take the responsibility of the consciousness raising process, which must follow the experimenting task activities. The consciousness raising part of the TBL method is a crucial for the success of TBL, it is here that the teacher must help learners to recognize differences and similarities, help them to "correct, clarify and deepen" their perceptions of the foreign language. He sums up that TBL is language learning by doing [3].

Task-based activities are aimed at practising reading and writing skills in meaningful contexts that often mimic real-life tasks and situations. Students train relevant functional language, at interacting and finally producing meaningful texts, which relate to real-life situations. TBL is really motivating for students, because TBL tasks are real, interactive and 
require group work. TBL also appeals to different learning styles, for example, auditory style - discussing the task and giving or listening to the presentations; kinaesthetic style - researching on the computer, in books and designing the presentation; visual style - looking at maps and pictures and designing the presentations. TBL can be cross-curricular and link with other subjects, e. g. geography. It usually starts from input from reading or listening. The students are required to complete the speaking or writing task. Therefore, they practise reading and writing meaningfully as learners must read and write to achieve the task so there is a genuine communicative goal. TBL can integrate reading and writing with speaking and listening. As a facilitator, the teacher gives students lots of free practice to develop learner autonomy: he monitors activities and is available to help if needed and corrects the final product. He also gets and keeps learners interested in the task; manages time; helps learners to brainstorm ideas; provides learners with functional language to do the task as well as monitors group work to make sure learners are on task.

All in all task-based learning is an approach where learners carry out tasks such as solving a problem or planning an activity. The language learnt comes out of the linguistic demands of the activity.

Mark Trevarton in his article "Remixing a grammatical syllabus" suggests that in a grammatical syllabus learners will learn the grammar and then use it. A task-based syllabus simply reverses this. They start by using grammar, trying to say what they really mean and then refining it where necessary [4].

For example, a teacher can tell their students about their experience of a flight delay in the airport. They can discuss common problems on holiday delays, bad weather, inability to pay the fees etc. The next step: learners tell each other about possible problems on holiday in a group of three. They choose the best holiday misfortune story and write it down together, concentrating on how to word the story. Final step: they retell their story to another group and decide on the best one. After this, there is a focus on form and grammar items based on learners' difficulties from the task, using the course book for support. Other lessons follow a similar pattern, and the language and grammar focus can even be set for homework. We can begin with a prediction task and learners are given clues and are asked to predict the content of a story based on the clues. The lessons then go on to do some detailed language work.

Jane Willis explores how to integrate a task-based approach into a typical textbook to maximize learning opportunities for your learners [5]. She defines differences between ordinary activities and tasks: tasks will not just be speaking to practise a new structure e.g. doing a drill or enacting a dialogue or asking and answering questions using the new patterns; or writing to display their control of certain language items,

Tasks are form-focused activities, designed to practise language items that have been presented earlier.

Dave and Jane Willis in their work "Doing Taskbased Teaching" offer the following criteria for identifying tasks for TBL in the form of questions. The more confidently you can answer yes to each of these questions, the more task-like the activity: 1) Will the activity engage learners' interest? 2) Is there a primary focus on meaning? 3 ) Is there a goal or an outcome? 4) Is success judged in terms of outcome? 5) Is completion a priority? 6) Does the activity relate to real world activities? [6].

Tasks can have various forms. In different text books they are presented with discussions, writing a blog or a comment, comparing ideas, work in pairs and teams, etc.

According to the criteria for identifying tasks for TBL there are several types of tasks: 1) listing and/or brainstorming; 2) ordering and sorting; 3 ) matching; 4) comparison; 5) problem-solving; 6) sharing personal experiences and storytelling [6]. We can also use quizzes, questionnaires and projects.

For example, at practical English grammar course for pre-service English teachers, while practicing Past Simple and Past Continuous students work in groups of four, the task of each group is to find out the evidence of the accident; practicing Present Perfect students work in small groups with two resumes and decide who to hire and why; listening and identifying pictures: learners listen to the conversations and try to match them to the correct picture - they put their hands up when they think they know which picture it is; learners have a class discussion: they talk about things that have changed or have been changing in the city or town, using Present Perfect and Present Perfect Continuous tenses [7].

The same with theoretical English grammar course - students work in pairs, in teams - they match linguistic notions with their definitions, underline the key words and phrases in the several definitions and create their own definitions; students can watch a video and they work in groups to make a list of characteristics they have noticed, draw a mind map or a metaphor etc. Here teachers can apply "theory through practice" approach.

We can differentiate activities given in the text books according to phases: pre-task activities, task planning - report cycle, post-task activities. The aim of pre-task or priming phase is to prepare learners for doing the main target task. For this they will need vocabulary to express the meanings they may wish to express when doing the target task.

The instructions at the report stage are "Now tell another pair your story/what you have done/Tell the class who you chose and say your reasons". At this 
stage, students want to use their best language - they will feel the need to plan well, use the right words, speak as fluently as they can and avoid mistakes.

If a planning stage is incorporated between the task and the report back stage, students will have a chance to focus on the language and grammar they want to use and improve it. Teachers act as language advisor, and students will be working at their own level, improving and extending the language and grammar they already have. Thus we achieve a student-centered focus on language in the context of the task.

During the final report phase, there is a simultaneous focus on fluency and accuracy, and the planning stage helps students to prepare for this [6].

Conclusions. To sum it up, we can assume that task-based approach to learning a foreign language, in particular English grammar, can be more efficient than PPT approach. Task-based language teaching is a student-centred approach to foreign language learning. TBL activities focus on having students use authentic target language in order to complete meaningful tasks, for example, they might work with realworld situations or other project-based assignments.

All in all, we believe that the process of taskbased learning teaches important skills. Students learn how to ask questions using different tense forms, how to negotiate meaning and how to inter- act in and work within groups. While working in the group, students can observe different approaches to problem solving as well as to find out how others think and make decisions.

\section{References:}

1. Bolitho Rod. Reconceptualizing Language Teacher Education for the $21^{\text {st }}$ Century. English Language and Development for the $21^{\text {st }}$ Century : Selected Papers. Kuala Lumpur: IPBA, 2002.

2. Rod Ellis. Task-based language learning and teaching. Oxford : Oxford University Press, 2003. $400 \mathrm{p}$.

3. Lewis Michael. The Lexical Approach. The State of ELT and a way forward. Heinle, 2002. 202 p.

4. Trevarton Mark. Remixing a grammatical syllabus. URL: https://www.teachingenglish.org.uk/blogs/ mark-trevarton/remixing-a-grammatical-syllabus.

5. Willis Jane. Criteria for identifying tasks for TBL. URL: https://www.teachingenglish.org.uk/article/ criteria-identifying-tasks-tbl.

6. Dave and Jane Willis. Doing Task-based Teaching. URL: https://ihjournal.com/doing-taskbased-teaching-2.

7. Fuchs M., Bonner M., Westheimer M. Focus on Grammar. Integrated skills approach. Third Edition. Students' book. Pearson Longman, 2006. $432 \mathrm{p}$.

\section{Гандабура О. В. Впровадження проблемно орієнтованого навчання у викладанні граматики} для майбутніх учителів англійської мови

У статті розглядається проблема переосмислення структури та забезпечення програм підготовки майбутніх учителів іноземних мов.

У статті показано різницю між традиційним підходом та проблемно орієнтованим навчанням під час викладання граматики для майбутніх учителів англійської мови. Автор дає визначення понять «завдання» та його характеристику, «проблемно орієнтоване навчання» та переваги, які учні можуть отримати від нього. Завдання - це свого роду план діяльності, який має ресурс для сприяння використанню іноземних мов у класі. Основними особливостями завдання $\epsilon$ 1) початкова увага до значення; 2) акцент на мовних фрормах; 3) увага на тому, як мова використовується в повсякденному житmi.

Проблемно орієнтоване навчання - це підхід, коли студенти виконують завдання, як-от вирішення проблеми чи планування діяльності, а вивчені мовні одиниці використовуються з мовних потреб певної діяльності. Переваги проблемно орієнтованого навчання: 1) студенти потрапляють у реальну ситуацію; 2) студенти використовують свої навички на своєму поточному рівні, щоб далі вдосконалювати володіння мовою; 3) студенти досягають своїх цілей там, де мова стає інструментом, що робить використання мови необхідним.

Описана роль викладача як фрасилітатора на занятті із проблемно орієнтованого навчання. Викладач повинен допомогти студентам розпізнати відмінності та подібності; допомогти покращити сприйняття іноземної мови.

Існують критерії для визначення завдань для проблемно орієнтованого навчання, подані у формі шести запитань. На основі цих критеріїв існує кілька типів завдань, як-от: створити перелік, мозковий штурм, узгодження, упорядкування та сортування, порівняння, вирішення проблем, обмін особистим досвідом та розповідь.

У статті представлені приклади граматичних завдань для проблемно орієнтованого навчання. Ці приклади стосуються практичного та теоретичного курсів граматики англійської мови. Автор використовує такі фрази видів діяльності у проблемно орієнтованому навчанні: підготовчу фразу, фразу планування завдання, фразу звіту та фразу після виконання завдання.

Ключові слова: завдання, проблемно орієнтоване навчання, граматика, критерії для визначення завдань, типи завдань. 